\title{
Joint Stock Companies in Kosovo's Financial Market: Problems with the Legal Framework
}

\author{
Submitted 05/02/19, 1st revision 25/02/19, 2nd revision 28/03/19, accepted 17/04/19
}

\author{
Armand Krasniqi ${ }^{1}$
}

\begin{abstract}
Purpose: The purpose of this paper focuses on the review of some legal features that prevent the extension and development of a joint stock companies in Kosovo.

Design/Methodology/Approach: The issue has been analyzed by comparing the legislation with several countries in the region alongside by identifying some of the substantial factors of why such a small number of joint stock companies are established in the business practice in Kosovo in relation to other countries, and once they are established, they are even less operative and operational.

Findings: Joint stock companies are established by the Law on Business Organizations, but denomination of titles by them should be regulated by the Law on Securities, in which case in Kosovo this regulation has not been issued nor harmonized.

Practical Implications: In fact, this phenomenon is in contrary with the extent and role of joint stock companies in developed market economies.

Originality/value: Disadvantages of these companies in our country are mainly related to the lack of law on securities, consequently also the regulatory institutions that cover this sector.
\end{abstract}

Keywords: Law, joint stock company, market, financial, securities.

JEL Codes: K22.

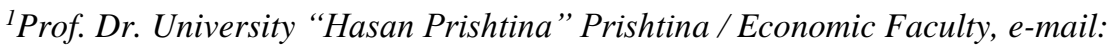
armand.krasniqi@uni-pr.edu
} 


\section{Introduction}

The research of this issue is done based on secondary data, namely from certain scientific and professional literature which to some extent were dedicated to the same or similar topics. In reality, by reviewing the literature, we came to understand that the issue we are presenting, at least until recently, was not subject to sufficient studies in almost any country in South Eastern Europe. Therefore, based on professional and scientific resources, indeed incomplete and unprocessed properly, we managed to create and present a solid theoretical framework about legal causes of the studied issue.

Through literature research, we have found a relatively small number of authors originating from countries that went through a transition phase from socialist economic systems to market economies. Most of them approach this subject in a similar way, providing recommendations for legal measures to address the problem, but without going into more detailed analysis of particular, or similar, conditions that the formation process and operation of joint stock companies are facing. Since, at least until now, this issue is very little researched even in broader doctrinal dimensions.

Thus, we are convinced that this paper could serve primarily as a source of information for the legislative institutions facing such situations. Use and analysis of legal grounds that were obtained based on a revision of legal acts and statistical data, resulting in the presentation of a small number of joint stock companies in relation to the number of other forms, should be seen as signals that the number subject to the terms of this legal framework risks that these joint stock companies not only could be transformed into limited liability companies, but also could be extinguished entirely (Tachmatzidi, 2018).

The reliability of analysis of causes that affect the small number of joint stock companies on the other hand should be seen as a legal choice to improve this situation (Rupeika-Apoga et al., 2018; Simberova and Rekova, 2016).

The purpose of this paper is limited to identifying and analyzing the legal causes that are affecting the registration and operation of a very small number of joint stock companies, not only in Kosovo, but also in the countries of the former Socialist Yugoslavia. Moreover, in this respect for comparison we have referred to the Albanian, Serbian and Bosnian law.

Despite the concerns raised, it should be noted that joint stock companies should be treated as legal forms that easily enable capital growth, and as such are among the most important forms of business organizations because there is a possibility to concentrate the capital from certain companies and many small resources shareholders (Emelkina, 2016). 
Now, there is no dilemma that Joint Stock Companies were created from special economic needs since other forms could not meet the specific needs of trade associations in order to carry out a particular trading activity commonly, under the same company (Woodward, 2014). Economic activities of modern business involve a large concentration of capital in order for the business enterprises to be successful (Morais Pereira and Candeias Bonito, 2018; Arize et al., 2018; Mahboud, 2017; Valencik and Cervenka, 2016).

Such a concentration of capital can be carried out by individual traders from their associations by borrowing ("Joint Stock Company": West's Encyclopedia of American Law, 2012) or other ways by issuing bonds, etc.

\section{Features of Legal Forms of Trade Companies in Kosovo}

According to the provisions of the current Law on Business Organizations, five legal forms of business organization (Investment in Kosovo, 2017) are regulated in Kosovo, such as:

Individual enterprises whose owner has unlimited liability for all the obligations of the company.

General partnership - a partnership where all partners respond without restriction and solidarity to the obligations of society.

Limited partnerships, despite the "unlimited" partners (partners respond without restriction and with solidarity to the obligations of the company), "limited" partners take part as well, or those partners who are responsible for the company's obligations to the limit of the value of their contributions.

Limited Liability Company (LLC) are companies that can be established by one or several legal entities or natural persons, who, for all the liabilities of the company, are only liable only for the share of capital deposited in the company and the Joint Stock Company (J.S.C) the capital of which is divided into shares and the shareholders are responsible for all debts and other liabilities with all assets and wealth deposited in this company (Investment in Kosovo).

The Law on Business Organizations also regulates the establishment and functioning of some other business companies that should have one of the five legal forms of the above-mentioned organization, like a foreign company, which upon registration in Kosovo is considered a subsidiary of the parent enterprise, which in this position does not have the identity of a legal person.

After registration, it has all rights and obligations established under the applicable law. After denomination it is evidenced as a "Branch in Kosovo"; Joint Stock Companies include a legal entity, most of the assets and capital of which are socially 
owned. These companies until privatization are monitored and registered by the Privatization Agency of Kosovo (Article 5 paragraph 2 of Law No. 06 / L-016).

Public enterprises are specific legal forms that carry out activities of general interest established by state institutions. Joint Stock Companies are monitored by the Government and are organized as a Joint Stock Company in accordance with the applicable law on commercial companies. All property interests of public enterprises are represented by shares and all such shares shall be registered $\left({ }^{1}\right.$ Law No. 03 / L087).

Agricultural Cooperative is a business organization created by natural or legal persons being all farmers who contribute their private property to share capital. The Agricultural Cooperative is established by at least five (5) farmers who are signatories to the obligations. A Cooperative will not be established without capital or will not even exist without capital (Law No. 2003/9).

\section{Views on Open or Closed Joint Stock Companies}

One of the main reasons for the interest of the entities to operate in the legal form as a joint stock company is exactly the right for shares, namely the issuance of shares. This form easily provides them with opportunities in respect of capital evaluation and capacity, to have a greater number of investors to finance high-cost projects. Therefore, shares have many advantages over the initial issue of enterprise financing (Ireland, 2010) because it allows capital to be collected by a large number of entities but with smaller roles in that foundation.

From literature search it turns out that not all the Southeast Europe countries, which in the last two or three decades have passed the transition phase from the centralized state economy to the market economy, have managed to consolidate all segments of economic state and, in particular, legislation and the financial market. Based on these circumstances, despite the similarities that forms of commercial companies have in their juridical sense, they have also resulted in substantial differences.

The differences that we find today in these states relate, in particular, to the type of legal form of a joint stock company (Iwasaki, 2014). Thus, it turns out that in some countries in practice, and in some countries even in relation to legal regulation, a joint stock company may be of the open (public) or closed type (Campbell, 2009).

If in the foundation act of a company does not mention its type, then the joint stock company is open. It is common practice that owners of an open joint stock company are recognized very rarely. Therefore, in some cases, such as, for example, in the Republic of Albania, the legislation for such companies uses the expression anonymous companies (Law No. 990, 2008). The reason is simple: Companies of open shares are generally large and have a large number of shareholders. According to some authors, the number of shareholders goes up to several million, in addition, 
stock is a stock is a value statement that is traded on an open stock exchange. Therefore, even in this form, Joint Stock Companies often change their owners (Deakin, 2009).

A closed joint stock company is a joint-stock company whose shares, in accordance with the law, are issued only to their founders, or to a limited number of other persons. A closed joint stock company can not register with public offering or offer its shares publicly (Iwasaki, 2007). If there are no restrictions on the transfer of shares, the number of shares in a company with the statute of a closed company is not specified and it is considered that shares of the company can be freely transferred.

Therefore, closed stock companies often consist of a few shareholders and there are restrictions on share trading. In fact, shares are not traded on the stock market despite the fact that open joint stock companies have no restrictions on the trading of their shares. They are freely traded on the share market and outside the exchange market. An open joint stock company is the one that, at the time of its establishment or after its establishment, makes a public invitation for registration and payment of shares. Public invitation is made with a public offer and prospectus in accordance with the regulations (Ljubisavljević \& Jovanović, 2011).

Kosovo since 1999 has regulated trade companies, respectively joint stock companies with three systematic laws. Each of these acts has regulated Joint Stock Companies roughly the same. The first legal act for regulating these companies was UNMIK Regulation no. 2001/6 (The wolf thesis guide to Kosovo, 2012).

According to this act, Joint Stock Companies and Limited Liability Companies are regulated in the corporate form. This law has not explicitly defined the fact that such a company should be precisely defined as an open type or a closed type (Regulation 2001/6, 2001). The Law on Business Organizations Nr. 02 / L-123, (2008), repealed in 2018, did not regulate nor mentioned the open or closed form of such companies. Also, the current law on Business Organizations no. 06 / L-016 does not recognize the operating form of the open or closed type joint stock companies. But if all is evaluated in terms of the legal framework shortages, it is clear that Joint Stock Companies in Kosovo are of closed type in practice.

In the comparative aspect, we conclude that the aspect of legal regulation of joint stock companies of the open or closed type is to be found in: the provision of Article 107 of the Law on Business Associations of the Federation of Bosnia and Herzegovina (Zakon o privrednom društvu FB i H), and the provision of Article 592, bullet 4, paragraph 4 of the Law on Business Organizations of Serbia (Zakon o gospodarskom društvu, 2018).

\section{Joint Stock Companies in the Local Legislation}


It is a notorious fact that today joint stock companies are the leader, respectively the most powerful and dynamic operators of the world economy. Their regulated and established management principles, specific organizational structures, the ability to provide significant funds for a short period of time with the participation of a large number of citizens, the fair distribution of earnings, and adjustment to market changes, have made joint stock companies the most well-known, or most important in the global goods, capital and labor market (Kasimoğlu, 2018). It should be noted that Kosovo has a weak and asymmetric financial system, with a partially developed banking sector and a modestly developed non-banking sector.

Thus, as part of the non-bank financial sector, Kosovo has a market with lack of capital market, resulting in certain licensed market operators (enterprises, custodians, investment funds, pension funds, life insurance etc.). In the domestic market, shares are among the weakest investor activities.

However, the fact of a small number of joint stock companies in Kosovo is present also in some countries that have emerged from the former socialist Yugoslavia. Based on the official statistical data below (Tables 1-3), for a very long period of time, it turns out that the legal form of a joint stock company is much smaller compared to the total number of business organizations. In fact, based on the official statistical data that we have shown in Table 1, the number of Joint Stock Companies in Kosovo was never more than $1 \%$ compared to other legal forms.

Therefore research of any dimension, from the scientific and social point of view, in terms of identifying the causes and circumstances of this situation, is fully justified. It should be noted that public enterprises in Kosovo also second-tier banks, including insurance companies, are registered only in the legal form of a joint stock company.

Table 1. Basic performance indicators for business registration in Kosovo

\begin{tabular}{|l|l|l|l|l|l|}
\hline Year & $\begin{array}{l}\text { Individual } \\
\text { Enterprise }\end{array}$ & $\begin{array}{l}\text { Partnership } \\
\text { Organization }\end{array}$ & $\begin{array}{l}\text { Commanding } \\
\text { Organization }\end{array}$ & $\begin{array}{l}\text { Limited } \\
\text { liability } \\
\text { Organization }\end{array}$ & $\begin{array}{l}\text { Joint Stock } \\
\text { Company }\end{array}$ \\
\hline $\begin{array}{l}1999- \\
2016\end{array}$ & 134,365 & 3,884 & 90 & 16,980 & $\mathbf{7 0 6}$ \\
\hline 2017 & 4,562 & 26 & 0 & 4,640 & $\mathbf{2 6}$ \\
\hline Total & 117,925 & 3910 & 90 & 21620 & $\mathbf{7 3 2}$ \\
\hline Total & \multicolumn{5}{|l}{} \\
\hline
\end{tabular}

Source: Statistical Agency in Kosovo, 2017 (ASK).

Table 2. Unregistered Business Organizations

\begin{tabular}{|l|l|l|l|l|l|}
\hline Year & $\begin{array}{l}\text { Individual } \\
\text { Enterprise }\end{array}$ & $\begin{array}{l}\text { Partnership } \\
\text { Organization }\end{array}$ & $\begin{array}{l}\text { Commanding } \\
\text { Organization }\end{array}$ & $\begin{array}{l}\text { Limited } \\
\text { liability } \\
\text { Organization }\end{array}$ & $\begin{array}{l}\text { Joint } \\
\text { Stock } \\
\text { Company }\end{array}$ \\
\hline $1999-$ & 12,212 & 340 & 1 & 452 & $\mathbf{2 9}$ \\
2016 & & & & \\
\hline
\end{tabular}




\begin{tabular}{|l|l|l|l|l|l|}
\hline 2017 & 1,440 & 24 & 0 & 111 & $\mathbf{3}$ \\
\hline Total & 13,652 & 364 & 1 & 563 & $\mathbf{3 2}$ \\
\hline Total & \multicolumn{4}{|l|}{} & 14,612 \\
\hline
\end{tabular}

Source: Statistical Agency in Kosovo (ASK).

Actually, these data although official, are only quantitative and, at least until now, no state agency or professional organization has conducted any profound and thorough research into the extent to which these companies are operational. However, the only one is the Institute for Advanced Studies GAP, which on a periodic basis addresses development policy issues only for public enterprises in Kosovo, as such being insufficient (GAP 2015).

It is of interest for the study to note that in the total number of companies registered in the form of a joint stock company are included private business companies, public enterprises and cooperatives of farmers. In this context, according to Article 21 of the Law on Banks, Microfinance Institutions and Non-Bank Financial Institutions, all entities performing banking and financial activity in the territory of Kosovo should be registered under the Law on Business Organizations only as a Joint Stock Company. This means that the law excludes the possibility for these institutions to act in any other legal form. (Law No. 04 / L-093). The same case is the establishment of agricultural cooperatives which are registered only as joint stock companies (Law No. 2003/9).

Table 3. Statistical Reports on the number of Joint Stock Companies in Kosovo

\begin{tabular}{|l|l|l|l|l|l|l|l|l|l|l|l|}
\hline Year & $\begin{array}{l}2004 \\
- \\
2008\end{array}$ & 2009 & 2010 & 2011 & 2012 & 2013 & 2014 & 2015 & 2016 & 2017 & $2018^{2}$ \\
\hline $\begin{array}{l}\text { Total } \\
\text { number of } \\
\text { registered } \\
\text { companies }\end{array}$ & 67950 & 74436 & 7729 & 7879 & 9592 & 9.421 & 9405 & 9811 & 10424 & 9,335 & 2,567 \\
\hline $\begin{array}{l}\text { No. of } \\
\text { joint stock } \\
\text { companies }\end{array}$ & 176 & 188 & 15 & 12 & 21 & 43 & 25 & 20 & 23 & 26 & 7 \\
\hline
\end{tabular}

Source: Kosovo Statistical Agency (ASK).

\section{Main Causes for the Small Number of Joint Stock Companies in Kosovo}

There is no dilemma that the causes for such a small number of Joint Stock Companies in Kosovo, particularly those in private capital, are numerous, complex, diverse and very profound, ranging from the context of historical development to the model and economic and social position of the country. However, within the scope of this paper, only those reasons that are related to the legal framework will be evidenced. From this point, we consider the following:

\footnotetext{
${ }^{2}$ Source: ARBK for 2018 data obtained only for 9 months (January-October 2018) https://arbk.rks-gov.net/page.aspx?id=1,41
} 
1. Lack of legislation for securities - financial titles: The country's competent institutions, even after many attempts, have not yet managed to issue the basic law (Hornuf \& Schwienbache 2017) which would regulate the general legal and economic aspects of securities - financial titles. In the absence of this law, it has not yet been possible to regulate issuance of securities, arranging transactions with these documents, including the establishment and functioning of authorized participants in the securities market, the creation and functioning of the stock exchange and other publicly regulated public markets, the creation and functioning of the central deposit of securities, protection of the interest of owner's security rights, and investors in the security market, public work in securities trading, organization and competence of the Kosovo Securities Commission, as well as other important issues for the successful functioning of the securities market.

2. Lack of Corporate Governance Legislation: Lack of legal framework for regulating corporate governance, in particular joint stock companies with private capital (Giovanna, Dennis \& Andrea, 2018). In this respect there is difference with public enterprises since some of them are at least formally incorporated and operate under this system.

3. Poor banking system: The centralized banking system, poor shareholder culture, and lack of state-institutional measures which do not know how to help develop the capital market, currently make Kosovo a record holder in the region with no organization of initial public offering for sale or eventual transfer of shares. Therefore, it is not surprising that joint stock companies are rarely established and that there is actually lack of market - stock market where they would be able to be traded.

4. The origin of the J.S.C., not from the privatization process: After 1999 up to now in Kosovo currently operate about 700 Joint Stock Companies (J.S.C.), and among them about 70 are public enterprises. In such circumstances, it is believed that this number is too large when taking into account the fact that most of these companies did not emerge from any privatization process. As such, currently remain banks (GAP, 2015) for the only reason because they are required to register in the form of a Joint Stock Company.

5. Lack of stock market: Joint Stock Companies, Second-Tier Banks and Public Enterprises in the capacity of Joint Stock Companies operating in Kosovo are not able to ensure their necessary capital through the stock exchange for successful operation.

6. Strict criteria for minimum foundation capital: Indeed, unlike the Limited Liability Company (LLC), for the Joint Stock Company (J.S.C.) there are more strict criteria regarding the value of the foundation capital, the transparency of 
operations (special requirements for public reporting for J.S.C. in the capital market) and responsibilities with property.

7. In certain cases the founder's risk for individual liability: In certain cases, the directors and members of the board of a joint stock company have the possibility to respond also with their property for the damage caused by violation of rules.

8. Tendency of transformation of JSCs into LLCs: In Kosovo, despite the existence of a small number of Joint Stock Companies, they are increasingly transforming into Limited Liability Companies. This, of course, is due to lowering their costs, but above all because of the possibilities for much more transparent operations. Based on the data provided by the Business Registration Agency, for seventeen years (1999 - 2016) a total of 706 Joint Stock Companies were registered, whereas in 2017 only 26 were registered. On the other hand, during the period (1999 - 2016), 29 were unregistered, and in 2017 a total of 3 were registered. Currently, most of these companies are either not fully operational or, even if they are functional, they are obliged to operate only as a closed-type joint stock company.

9. Current Benefits of Operating as a LLC: In the absence of the above-mentioned legal framework for successful operation of joint stock companies, the preference of investors to choose the form of the limited liability company is as follows: turnover of shares is carried out without mediation of the Stock Exchange institution; further repayment of shares of minority owners by the majority owner is done without the implementation of a complicated public offering procedure for taking shares; there are no restrictions on price determination when buying shares from the remaining owners; greater control over trading of company's shares is done through the realization of prepayment rights by the existing shareholders; increase of capital with new deposits (monetary or non-monetary) is done without the consent of the Securities Commission; greater freedom in determining the bodies of company (no obligation regarding the existence of the Board of Directors) and relations between the co-owners; risk of enforcing legal fines is reduced due to the nonimplementation or absence of a deadline for executing specified actions for a company; there is no obligation to create and continually renew the prospectus for stock exchange trading; smaller obligations for public information on important events; the possibility of using a legal form change to buy shares from small shareholders at market value, or the possibility of small shareholders to exercise the right to acquire the market value of their shares, etc. In this way, significant savings are achieved in operating costs.

\section{Conclusion}

A joint stock company is a legal person with responsibility for its own liabilities and only with its own capital. It is created by capital associations of some persons - 
founders and based on the shares acquired. Its establishment is based on a founding contract, and if it is founded by one member it is then constituted by a decision for establishment. The basic agreement is a formal act and should be done in writing. Economy today is dominated by joint stock companies. Globally, multinationalshare companies are more powerful than many countries and dictate the development of global economy. Worldwide there are many capital markets where shares are traded. In there the capital in the form of shares goes through constant transformation and ownership change, enabling a better business idea to get the best chance.

Unlike other legal forms of business organizations in Kosovo, including some countries from the former Socialist Yugoslavia, the situation of their establishment and operation is different. In Kosovo, based on statistical data, it was found that Joint Stock Companies almost from 1999 up to now are very small in number in relation to other forms of companies. It is not disputable that the causes and circumstances about this phenomenon are complex and of social-economical and legal character.

This paper is focused only on identifying legal issues related to the legislative aspects. Kosovo from 1999 until now has managed to issue legislation on the regulation of business organization and other enterprises, but even after many attempts, has failed to complete the legislation and institutions for issuing and controlling financial titles. Lack of this wide-ranging legislative basis and in respect of non-harmonization and non-synchronization, it is one of the main reasons for the small number of joint stock companies.

Under these circumstances, joint stock companies, although this issue is not explicitly regulated by law, act and operate in Kosovo only as closed joint stock companies, which means that they only provide shares to their founders or to a limited number of other persons. Under these circumstances, these companies cannot register with public offering or to offer its shares publicly. Meanwhile, open type joint stock companies are created by collecting successive funds by sending a public invitation to third parties for registration and payment of shares, which is not in practice in Kosovo.

Shortcomings in the legal framework are evident in respect of lack of primary and secondary legal acts for securities corporate and corporate management. As a consequence of this absence, the situation has become more complicated not only because of the smaller tendency for registration of shareholding companies, but also transformation of those registered into a limited liability company.

Political and law-making institutions must finally understand that regulation of the legislative base for normal and natural operation of these business organizations may have a much greater impact on the economic development of the country. Only 
through these legal forms there are more chances for investments. These forms enable and facilitate more of the new technology which is necessary for our country.

Therefore, the state interest is that joint stock companies do not change the legal form get closed, but rather remain open. In addition, there is a direct interest of the state for transparent huge businesses, as it is perhaps easier for the joint stock companies to raise public revenues. In these companies there is more financial reporting developed, more powerful control mechanisms, and there is likely to be far less room for fiscal evasion.

\section{References:}

Article 5 paragraph 1 of Law Nr. 06/L -016 for Business Organizations.

Article 5 paragraph 2 of Law Nr. 06/L -016 for Business Organizations.

Arize, C.A., Andreopoulos-Campanelli, G., Kallianiotis, N.I. \& Malindretos, J. 2018. MNC Transactions Foreign Exchange Exposure: An Application. International Journal of Economics \& Business Administration, 6(1), 54-60.

Campbell, C. 2009. Legal Aspects of Doing Business in Europe. Publisher Lulu.com, ISBN 055721338X, 9780557213382, https://books.google.com/books?id=cxoxX5Z7BlwC\&source=gbs_navlinks_s

Deakin, S. 2009. Legal origin, juridical form and industrialization in historical perspective: the case of the employment contract and the joint-stock company. Socio-Economic Review, Volume 7, Issue 1, 35-65, https://doi.org/10.1093/ser/mwn019, https://academic.oup.com/ser/article-abstract/7/1/35/1689155.

Emelkina, A.I. 2016. Problems of Improving Russian Legislation on Property Rights and Other Proprietary Interests. European Research Studies Journal, 19(3) Part B, 170186.

GAP. 2015. Public Enterprises Legislation and Cooperation with Official Institutions http://www.institutigap.org/documents/77673_NP\%20online\%20pdf.pdf.

Hornuf, L. \& Schwienbache, A. 2017. Should securities regulation promote equity crowdfunding? Small Business Economics, Volume 49, Issue 3, 579-593, https://link.springer.com/article/10.1007/s11187-017-9839-9.

https://arbk.rks-gov.net/desk/inc/media/89559804-7DF3-46C4-A3A7-DF4A1DB15ED4.pdf. https://mti.rks-gov.net/desk/inc/media/1 AE022C6-8DBB-4227-B0AC-07EDF403C5F3.pdf. https://mti.rks-gov.net/desk/inc/media/1 AE022C6-8DBB-4227-B0AC-07EDF403C5F3.pdf.

Ichiro, I. 2014. Corporate Form, Institutional Complementary, and Organizational Behavior: Open versus Closed Joint-Stock Companies in Russia,. Corporate Governance in Emerging Markets, 157-195, DOI https://doi.org/10.1007/978-3-642-44955-0_7 Publisher Name Springer, Berlin, Heidelberg.

Ichiro, I. 2007. Legal Forms of Joint-Stock Companies and Corporate Behavior in Russia. Problems of Economic Transition, 50(5), 73-86.

Joint Stock Company. 2012. West's Encyclopedia of American Law, http://legaldictionary.thefreedictionary.com/Joint+Stock+Company.

Kasimoğlu, M. 2018. Survival strategies for companies in global Business World - A case study, http://info.opf.slu.cz/vvr/akce/turecko/pdf/Kasimoglu.pdf.

Kosovo Statistics Agency. 2017. http://ask.rks-gov.net/sq/agjencia-e-statistikave-tekosoves/ekonomi/regjistri-statistikor-i-bizneseve.

KPMG in Kosovo. 2017. Investment in Kosovo, Edition 2017, 
Joint Stock Companies in Kosovo's Financial Market: Problems with the Legal Framework

https://assets.kpmg/content/dam/kpmg/bg/pdf/Investment-in-Kosovo-2017.pdf.

Law no. 04/1-093 on Banks Microfinance Institutions and Non-bank financial Institutions https://www.bqkkos.org/repository/docs/2012/Ligji\%20per\%20bankat\%20IMF.pdf.

Law no. 2003/9 Law on farmer's cooperatives, https://gzk.rksgov.net/ActDocumentDetail.aspx?ActID=2472 https://www.researchgate.net/publication/5173412_Legal_Forms_of_JointStock_Companies_and_Corporate_Behavior_in_Russia.

Law No.9901, date 14.4.2008 - For businessmen and Business Organizations,. Republic of Albania, http://ligjet.info/shoqerite_tregtare/tsht/ligje/9901.

Law No. 02/L-123 for Business Organizations, the Official Gazette of the Republic of Kosovo / Prishtina: Year III / No. 39 / 01 October 2008, https://gzk.rksgov.net/ActDocumentDetail.aspx?ActID=2585.

Law no. 03/L-087 for public enterprises, https://gzk.rksgov.net/ActDocumentDetail.aspx?ActID=2547.

Law No. 06/L -016 for Business Organizations, the Official Gazette of the Republic of Kosovo / Nr. 9 / 24 May2018, Prishtina, https://gzk.rksgov.net/ActDocumentDetail.aspx?ActID=16426.

Mahboud, R. 2017. Main Determinants of Financial Reporting Quality in the Lebanese Banking Sector. European Research Studies Journal, 20(4B), 706-726.

Michelon, G., Patten, M.D. \& Romi, M.A. 2018. Creating legitimacy for sustainability assurance practices: evidence from sustainability restatements. European Accounting Review, https://doi.org/10.1080/09638180.2018.1469424 https://www.tandfonline.com/doi/full/10.1080/09638180.2018.1469424.

Morais Pereira, M.V., Candeias Bonito Filipe, A.J. 2018. Quality of Board Members' Training and Bank Financial Performance: Evidence from Portugal. International Journal of Economics \& Business Administration, 6(3), 47-79.

Paddy, I. 2010. Limited liability, shareholder rights and the problem of corporate irresponsibility. Cambridge Journal of Economics, 34, 5, 837-856, https://doi.org/10.1093/cje/ben040,.https://academic.oup.com/cje/article/34/5/837/17 00679 .

Regulation no. 2001/6 8 February 2001 for Business Organizations, http://www.unmikonline.org/regulations/unmikgazette/03albanian/A2001regs/RA20 01_06.pdf.

Rupeika-Apoga, R., Zaidi, H.S., Thalassinos, E.Y. \& Thalassinos, I.E. 2018. Bank Stability: The Case of Nordic and Non-Nordic Banks in Latvia. International Journal of Economics \& Business Administration, 6(2), 39-55.

Simberova, I. and Rekova, E. 2016. Phenomenon of "Born Globals“ in the internationalization of small and medium-sized enterprises in the Czech Republic. European Research Studies Journal, 19(4), 120-129.

Tachmatzidi, I. 2018. Takeover Defenses in the United Kingdom. International Journal of Economics \& Business Administration, 6(4), 105-118.

The wolf theiss guide to Kosovo: Corporate, Tax- \& other Regulations. 2012. WOLF THEISS Rechtsanwälte GmbH Schubertring 61010 Vienna 2012, https://www.wolftheiss.com/fileadmin/content/3_regionalDesks/The_Wolf_Theiss_ Guide_to_Kosovo_-_Corporate_Tax-_and_other_Regulations_3rd_edition.pdf.

Valenčík, R., Červenka, J. 2016. Analysis Tools of Connecting Investment Opportunities and Investment Means in the Area of Small and Medium-Sized Enterprises. European Research Studies Journal, 19(4), 130-139.

Woodward, S.N. 2014. Business organization, https://www.britannica.com/topic/business- 
Organization.

Zakon o privrednim društvima ("Sl. glasnik RS", br. 44/2018) stupio je na snagu 9. juna 2018. godine. https://www.paragraf.rs/propisi/zakon-o-privrednim-drustvima.html.

Zakon o privrednim društvima FB i $\mathrm{H}$, https://advokat-

prnjavorac.com/zakoni/Zakon_o_privrednim_drustvima_FBiH.pdf. 